\title{
La termografía infrarroja: posibilidades y aplicación al estudio superficial de los materiales
}

\section{Infrared thermography: possibilities and application to the study of material surfaces}

\begin{abstract}
RESUMEN
Las técnicas de medida no destructivas se están perfilando como un elemento muy importante en los distintos campos de investigación por su propio carácter. El equipo de Materiales del ICCET está desarrollando, desde hace algún tiempo, la aplicación de una de estas técnicas; concretamente la termografía infrarroja al seguimiento $y$ cuantificación de humedades presentes en edificios del Patrimonio Arquitectónico. De cualquier manera, dicha técnica puede ser aplicable a cualquier fenómeno físico que conlleve una variación de temperatura o emisividad. En el presente trabajo se muestran distintas posibilidades de aplicación de la Termografía Infrarroja.

Fecha de recepción: 2-V1-92.
\end{abstract}

\author{
E. GAYO, A. PALOMO, A. MACIAS \\ ICCET/CSIC \\ ESPAÑA
}

\begin{abstract}
$S U M M A R Y$
Non-destructive measurement techniques are revealing themselves as a very important tool in the different fields or research due to their very own nature. The Materials team of ICCET is developing, since some time ago, the application of one of these techniques - specifically speaking, infrarred thermography - to the follow-up and quantification of the moisture present in the buildings of the Architectural Heritage. At all events, that techique can be applied to any physical phenomenon involving a variation of temperature or emissivity. This paper shows different possible applications of infrared thermography.
\end{abstract}

\section{INTRODUCCIÓN}

La Termografía Infrarroja es un método de medida de la radiación emitida por la superficie de un cuerpo en la banda de longitudes de onda 2-5,6 $\mu$. Según la Ley de Planck, una vez fijada la banda de longitudes de onda, la radiación emitida por el cuerpo dependerá de su temperatura y emisividad. Por tanto, si una de estas variables es conocida a través de la Termografía Infrarroja se podría conocer la otra, bien puntualmente o bien en su evolución, tanto con el tiempo como a lo largo y ancho de una superficie.

Desde el punto de vista del observador, o de la persona que realiza el ensayo, el equipo de termovisión muestra una imagen en tono de grises de la superficie a estudiar que representa una distribución de isolíneas de igual radicación. Esta imagen, denominada termografía, ofrece una primera idea cualitativa del comportamiento térmico de la superficie.

\section{INTRODUCTION}

Infrared thermography is a method for measuring the radiation emitted by the surface of a body within the wavelength band 2-5.6 $\mu$. According to Planck's law, once the wavelength band has been determined, the radiation emitted by the body will depend on its temperature and emissivity. Consequently, if one of these parameters has been determined by infrared thermography, the other could be determined, either punctually or in its evolution both with time and across a surface.

From the wiewpoint of the observer or of the person carrying out the test, the thermovision equipment shows an image -in the grey tonesof the surface to be studied, which represents a distribution of the isolines with the same radiation. This image, called thermograph, affords a first qualitative idea of the thermal behaviour of the surface. 
En el presente trabajo, se discuten distintas posibles aplicaciones de esta técnica, así como sus limitaciones en cada caso.

\section{EXPERIMENTACIÓN}

El método experimental a seguir en cada caso dependerá, en primer lugar, de si se desea hacer una medida de laboratorio o una medida in situ. En el primer caso, todas las posibles variables que afectan a la medida son controlables y se pueden mantener constantes en su mayoría, mientras que en el segundo caso debemos considerar las perturbaciones que puedan afectar a la medida.

Inicialmente, la Termografía Infrarroja nos ofrece únicamente una medida cualitativa de variación en la superficie de estudio. Esta medida puede ser suficiente en algunos casos, por ejemplo cuando buscamos fugas térmicas o puntos calientes en una línea de tensión. En ambas situaciones tendríamos emisividad constante (por tratarse del mismo material siempre o de materiales muy parecidos) y podriamos interpretar la diferencia de isolíneas como cambios de temperatura.

Para la realización de medidas cuantitativas necesitamos el conocimiento previo de una de las variables. Se plantean dos tipos de medida:

- Medidas directas. La temperatura en cada caso se mide con termopares. Mediante termografía se determinan los puntos a medir $y$, una vez medida la temperatura superficial, se estudian diferencias de emisividad.

- Medidas relativas. Se usa una referencia de emisividad conocida en contacto térmico con el objeto. Sobre la referencia se calcula la temperatura de superficie (igual para objeto y referencia) y una vez conocida ésta se mide la emisividad sobre el objeto.

También, se discute en el trabajo la incidencia de posibles errores introducidos en la medida:

- Atenuación atmosférica.

- Ángulo de incidencia.

- Presencia de otros cuerpos radiantes o de fuentes luminosas o calóricas que irradian sobre la superficie de estudio.

- Factores meteorológicos.

- Posibles cambios de material en la superficie de estudio.
In this paper, different possible applications of this technique are discussed, as well as its limitations in each particular case.

\section{EXPERIMENTAL}

The experimental method to be followed in each particular case will depend in the first place on wheter a laboratory measurement or an in situ measurement is contemplated. In the former case, all possible variables affecting the measurement can be controlled, and most of them can maintained constant, while in the latter case the disturbances that can affect the measurement should be considered.

In principle, infrared thermography just offers a qualitative measurement of the radiation variation on the surface studied. This measurement can be sufficient in some cases, for example when searching for thermal leaks or hot points in an electric transmission line. In both cases, there will be a constant emissivity (since the material is always the same or the materials are very similar) and the isoline differences can be interpreted as temperature changes.

To carry out qualitative measurements, it is necessary to know in advance one of the variables. Two types of measurement occur:

- Direct measurments. The temperature is measured in each case with the aid of thermocouples. The points to be measured are determined by thermography and, after the surface temperature has been measured, the differences in emissivity are studied.

- Relative measurements. A reference of know emissivity in thermal contact with the object is used. The surface temperature (which is equal for the object and the reference) is calculated on the reference and, once this is known, the emissivity on the object is measured.

The paper also discusses the influence of the possible errors introduced in the measurement:

- The atmospheric attenuation.

- The incidene angle.

- The presence of other radiant bodies or of light or heat sources irradiating on the surface studied.

- Weather factors.

- Possibles changes of material on the surface studied. 


\section{RESULTADOS}

\subsection{Métodos cuantitativos}

Las fotografías 1 y 2 son un ejemplo de medidas relativas. Corresponden a una mancha de humedad producida por una avería en la red de saneamiento de un edificio. Se presentan dos termografías de la misma zona, una en modo continuo (Foto 1) y otra en escala de grises (Foto 2) (1).

Se obtienen los resultados representados en la tabla 1.

Como referencia se utiliza cinta aislante de emisividad previamente calculada.

\section{RESULTS}

\subsection{Quantitative methods}

Thermographs nos. 1 and 2 are examples of relative measurement. They belong to a wetness stain produced by a leak in the plumbing system of a building. Two thermographs of the same area are presented: a) a continuous thermograph

(Therm. 1) and b) a thermograph in the grey scale (Therm. 2) (1).

The following results have been found:

As a reference, an insulating tape has been used, the emissivity of which had previously been calculated.

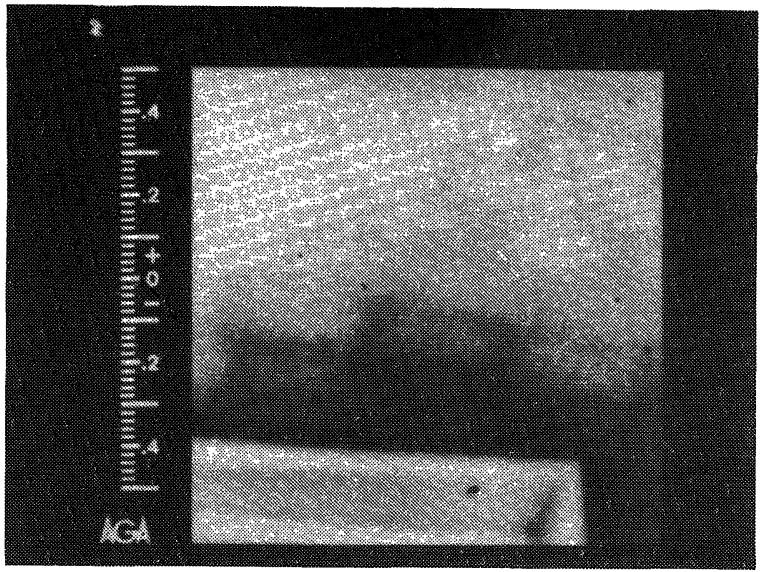

Foto 1

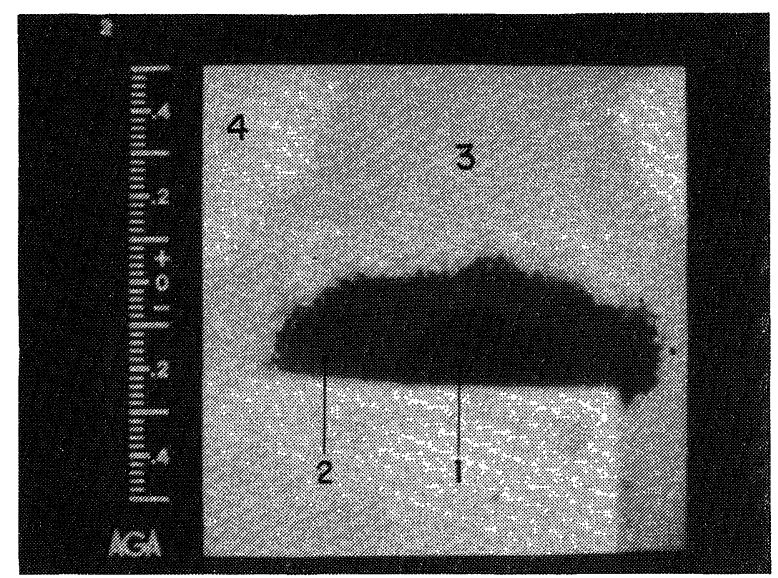

Foto 2

TABLA 1 TABLE 1

Variaciones en la temperatura superficial y emisividad del primer ejemplo (Variations in the surface temperature and in the emissivity of the first example)

\begin{tabular}{|l|c|c|c|c|}
\hline & Zona I (Zone I) & Zona II (Zone II) & Zona III (Zone III) & Zona IV (Zone IV) \\
\hline $\begin{array}{l}\text { T. sup. }\left({ }^{\circ} \mathrm{C}\right) \\
\text { Surf. } \mathrm{t}\left({ }^{\circ} \mathrm{C}\right)\end{array}$ & 15.9 & 16.4 & 17.0 & 17.7 \\
\hline $\begin{array}{l}\text { Emisividad } \\
\text { (Emissivity) }\end{array}$ & 0.72 & 0.70 & 0.68 & 0.68 \\
\hline
\end{tabular}

(1) Una termografía en modo continuo muestra la imagen de la superficie de estudio en una escala continua de grises, donde los tonos más oscuros corresponden con las zonas menos radiantes; una termografía en escala de grises muestra la misma imagen pero en una escala no continua de grises. En cada ejemplo, se presenta una termografía en modo normal y una en escala de grises.
(1) A thermograph in the continuous mode shows the image of the surface studied in a continuous scale of grey, where the darker tones correspond to the less radiant spots; a thermograph in the grey scale shows the same image, but in a discontinuous scale of grey For each example, a thermograph in the continuous mode and another in the grey scale are given. 


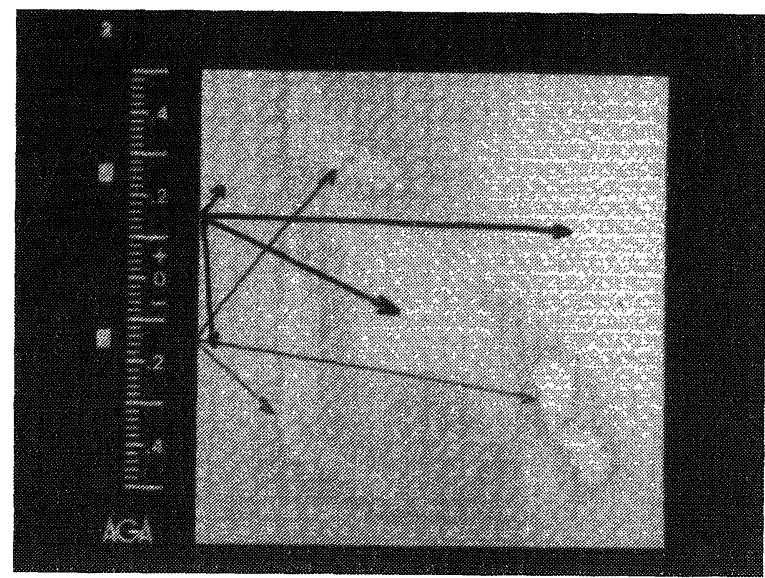

Foto 3

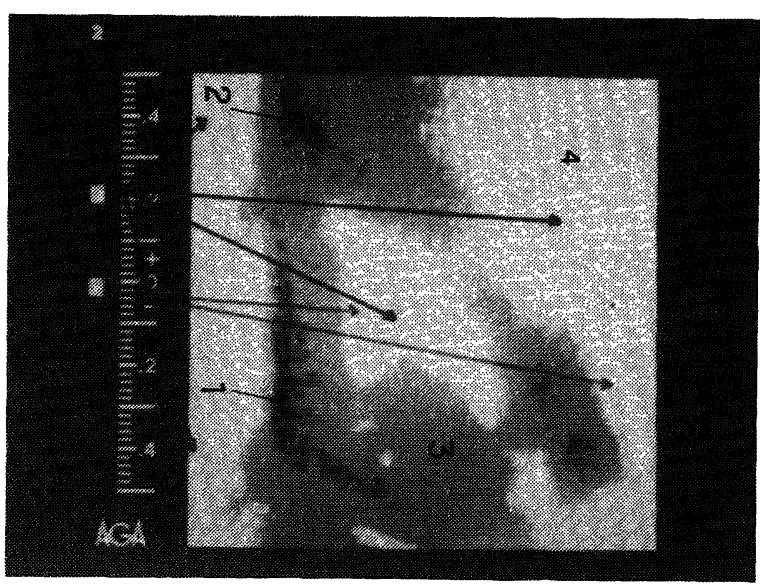

Foto 4

TABLA 2 TABLE 2

Variaciones en la temperatura superficial y la emisividad del segundo ejemplo (Variations in the surface temperature and in the emissivity of the second example)

\begin{tabular}{|l|c|c|c|c|c|}
\hline & Zona I (Zone I) & Zona II (Zone II) & Zona III (Zone III) & Zona IV (Zone IV) & Zona V (Zone V) \\
\hline $\begin{array}{l}\text { T. sup. }\left({ }^{\circ} \mathrm{C}\right) \\
\text { Surf. }\left({ }^{\circ} \mathrm{C}\right)\end{array}$ & 16.9 & 17.5 & 18.5 & 18.3 & 19.5 \\
\hline $\begin{array}{l}\text { Emisividad } \\
\text { (Emissivity) }\end{array}$ & 0.76 & 0.74 & 0.70 & 0.70 & 0.68 \\
\hline
\end{tabular}

En las fotografías 3 y 4 se muestra un ejemplo de medida absoluta. Corresponde también a una mancha de humedad producida por una avería en la red de saneamiento. En este caso, las temperaturas se miden con termopares y las emisividades con termografía. Se obtuvieron los resultados que se representan en la tabla 2 .

Las fotografías 5, 6, 7 y 8 muestran un ejemplo de la atenuación producida por la capa de aire cuando la distancia cámara-objeto es muy grande. En las tablas 3 y 4 se presentan los resultados obtenidos para la misma mancha de humedad en el mismo momento (por tanto no hay variaciones de ambientales) y a distintas distancias.

En todos los casos las emisividades se miden con un error del $30 \%$ y las temperaturas con el $5 \%$.

\subsection{Métodos cualitativos}

Las fotografías $9,10,11$ y 12 corresponden a la superficie frontal de una estufa que se encuentra a $927^{\circ} \mathrm{C}$. En las fotografías 9 y 10 se recoge toda la superficie de dicha estufa. Se observa un cambio importante de temperatura en el ángulo superior izquierdo, que queda representado por un cambio en el tono de gris (recordar que es este caso $\varepsilon=$ cte.). Las fotografías 11 y 12 se centran en esta zona en la que se observa la parte más caliente de la carcasa de la estufa.
In thermographs 3 and 4, an example of absolute measurement is shown. It also corresponds to a wetness stain produced by a leak in the plumbing system. In this case, temperature is measured by thermocouples and emissivity by thermography. Results are shown in table II.

Thermographs 5, 6, 7 and 8 are examples of the attenuation produced by the air -layer when the camera- objet distance is very large. Tables 3 and 4 shown the results obtained for the same wetness stain at the same time (therefore with no environmental variations) and at different distances.

In all cases, emissivity has been measured with an error of 30 per cent and temperature with an error of 5 per cent.

\subsection{Qualitative methods}

Thermographs 9, 10, 11 and 12 correspond to the front surface of an oven at $927^{\circ} \mathrm{C}$. Thermographs 9 and 10 cover the whole surface of the oven. An important change of temperature is observed at the left top angle, which is represented by a change in the grey tone (it must be borne in mind that in this case $\varepsilon=$ constant). Thermographs 11 and 12 are centered on this area, where the hottest part of the oven casing is observed. 


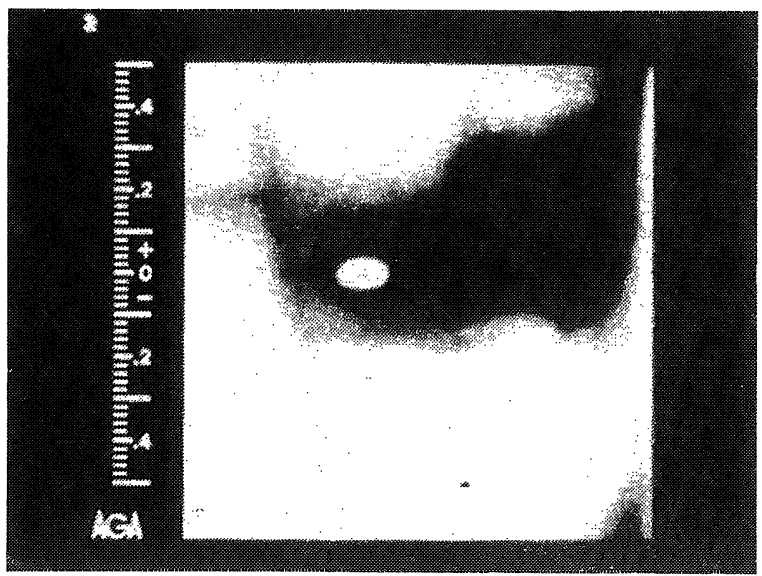

Foto 5

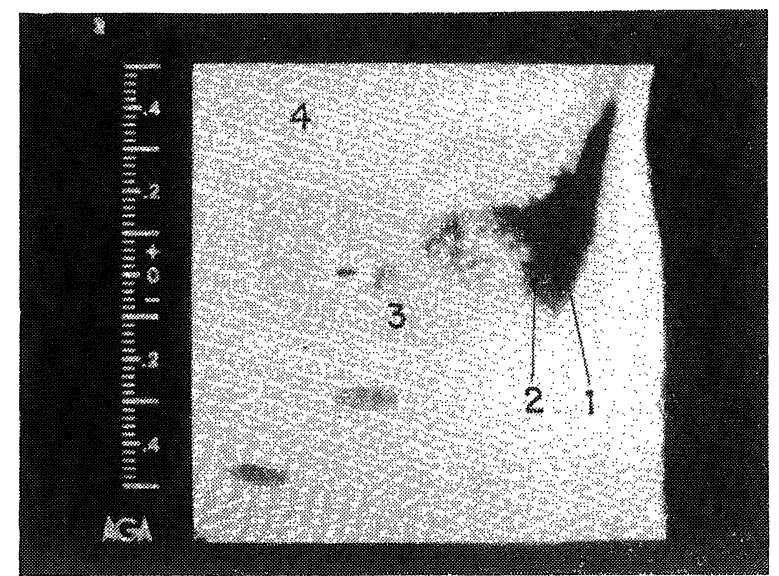

Foto 6

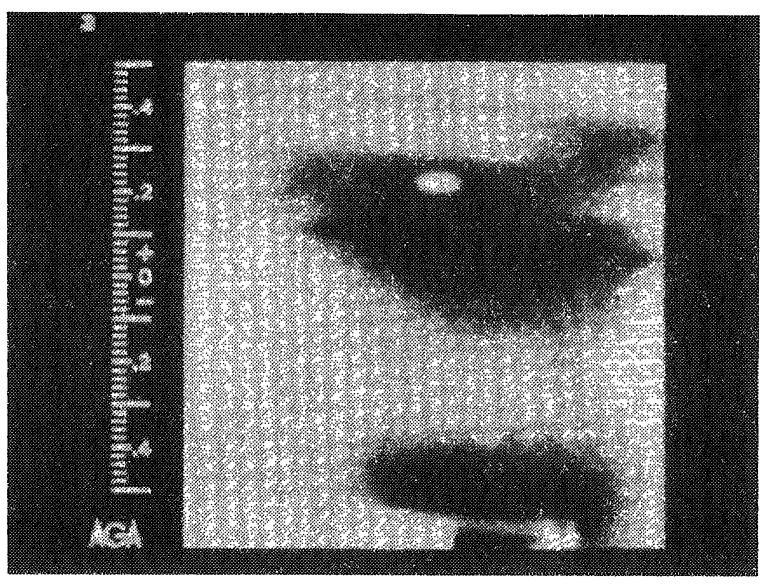

Foto 7

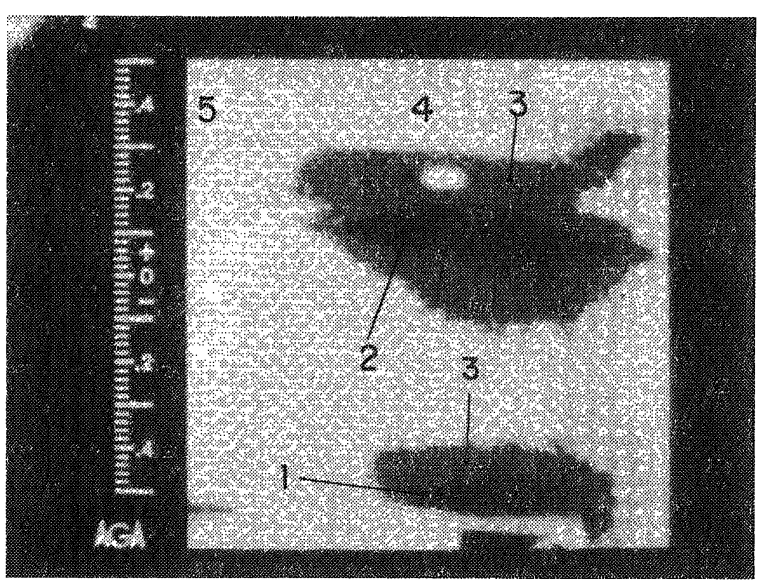

Foto 8

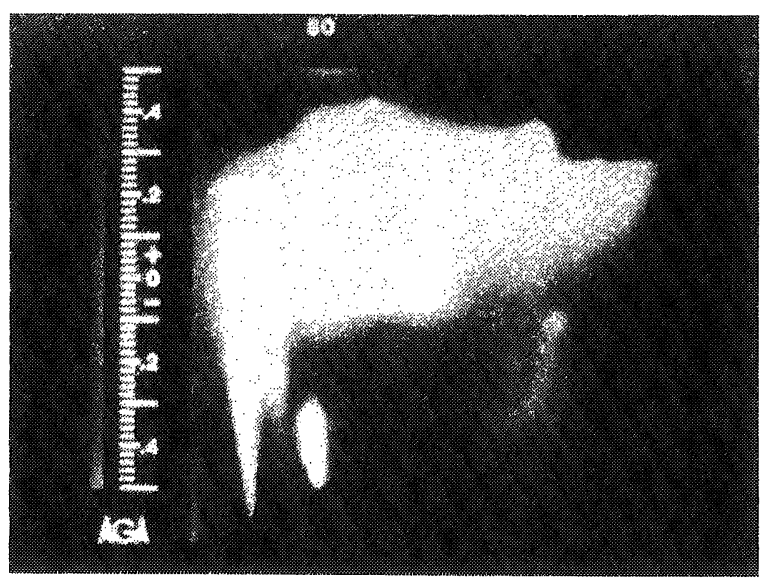

Foto 9

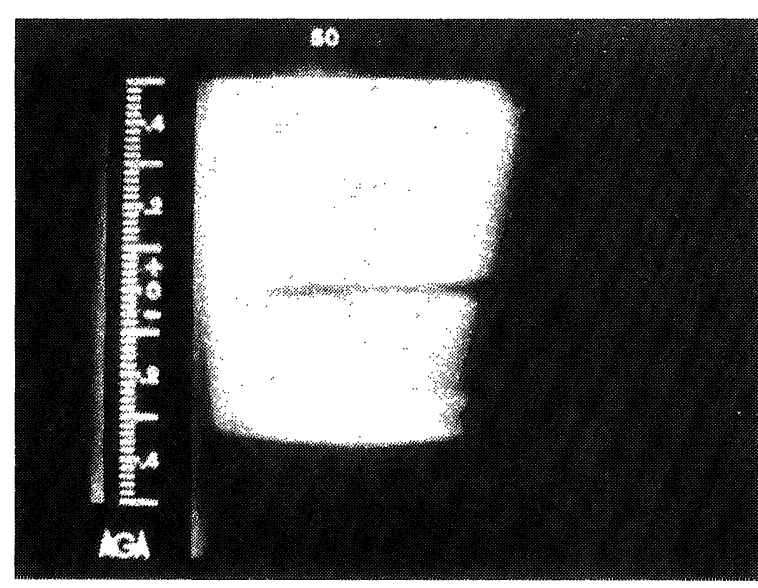

Foto 10 


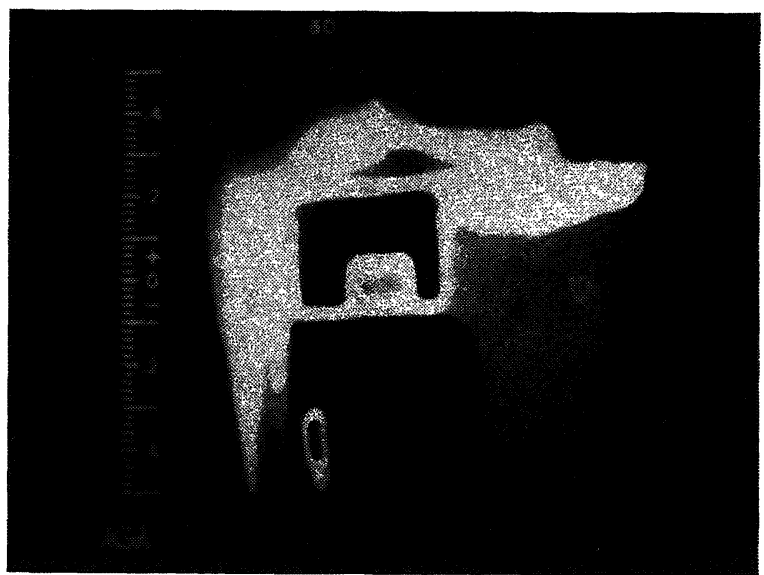

Foto 11

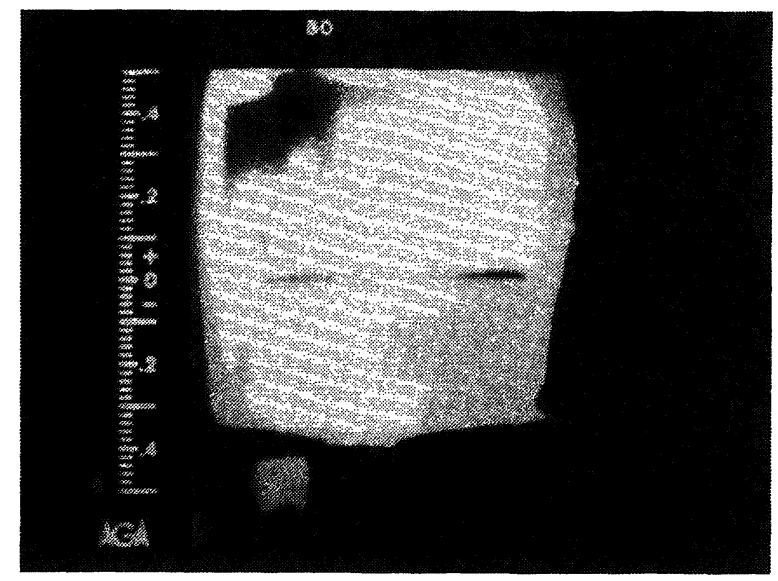

Foto 12

TABLA 3 TABLE 3

Variaciones de temperatura superficial y emisividad del tercer ejemplo (distancia $10 \mathrm{~m}$; fotografías 5 y 6)

[Variations in the surface temperature and in the emissivity of the third example (distance $10 \mathrm{~m}$; termographs 5 and 6)]

\begin{tabular}{|l|c|c|c|c|}
\hline & Zona I (Zone I) & Zona II (Zone II) & Zona III (Zone III) & Zona IV (Zone IV) \\
\hline $\begin{array}{l}\text { T. sup. }\left({ }^{\circ} \mathrm{C}\right) \\
\text { Surf. } t\left({ }^{\circ} \mathrm{C}\right)\end{array}$ & 13.8 & 15.5 & 15.4 & 16.0 \\
\hline $\begin{array}{l}\text { Emisividad } \\
\text { (Emissivity) }\end{array}$ & 0.74 & 0.74 & 0.74 & 0.70 \\
\hline
\end{tabular}

TABLA 4 TABLE 4

Variaciones de temperatura superficial y emisividad del tercer ejemplo (distancia $7 \mathrm{~m}$; fotografías 7 y 8 )

[Variations in the surface temperature and in the emissivity of the third example (distance $7 \mathrm{~m}$; termographs 7 y 89]

\begin{tabular}{|l|c|c|c|c|c|}
\hline & Zona I (Zone I) & Zona II (Zone II) & Zona III (Zone III) & Zona IV (Zone IV) & Zona V (Zone V) \\
\hline $\begin{array}{l}\left.\text { T. sup. ( }{ }^{\circ} \mathrm{C}\right) \\
\left.\text { Surf. t ( }{ }^{\circ} \mathrm{C}\right)\end{array}$ & 12.9 & 13.4 & 13.8 & 15.2 & 15.6 \\
\hline $\begin{array}{l}\text { Emisividad } \\
\text { (Emissivity) }\end{array}$ & 0.74 & 0.74 & 0.72 & 0.72 & 0.72 \\
\hline
\end{tabular}




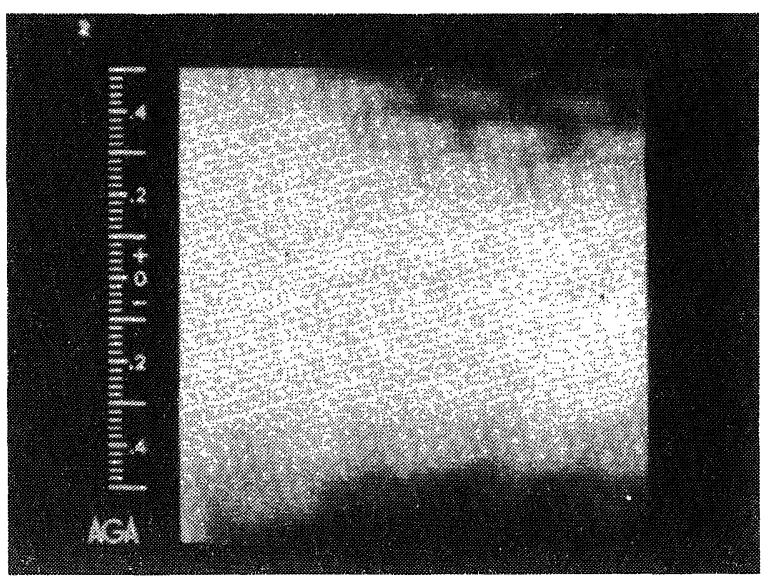

Foto 13

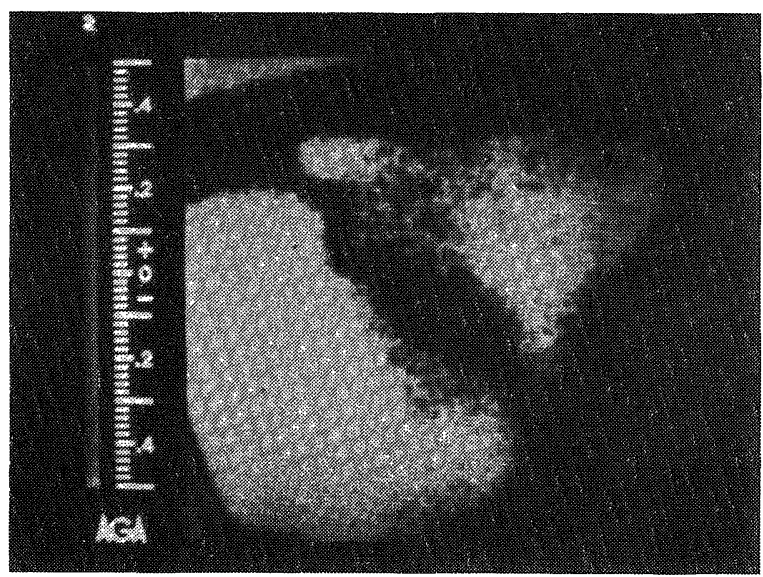

Foto 15

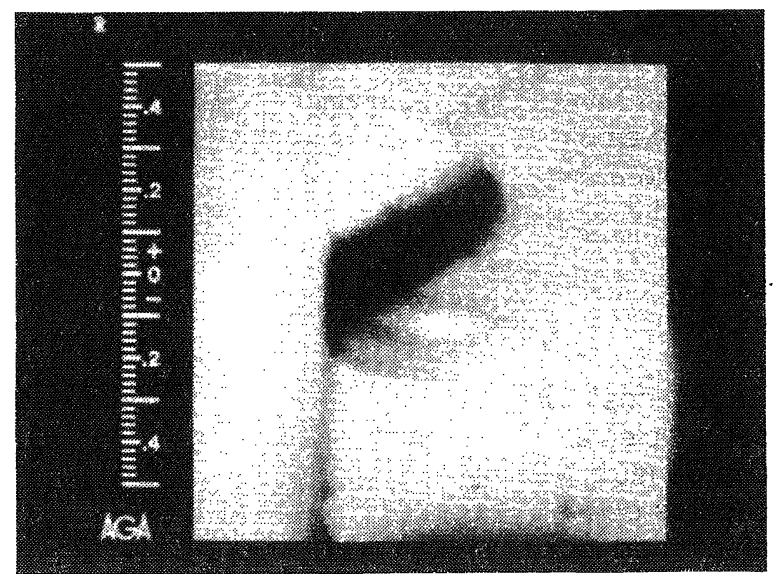

Foto 14

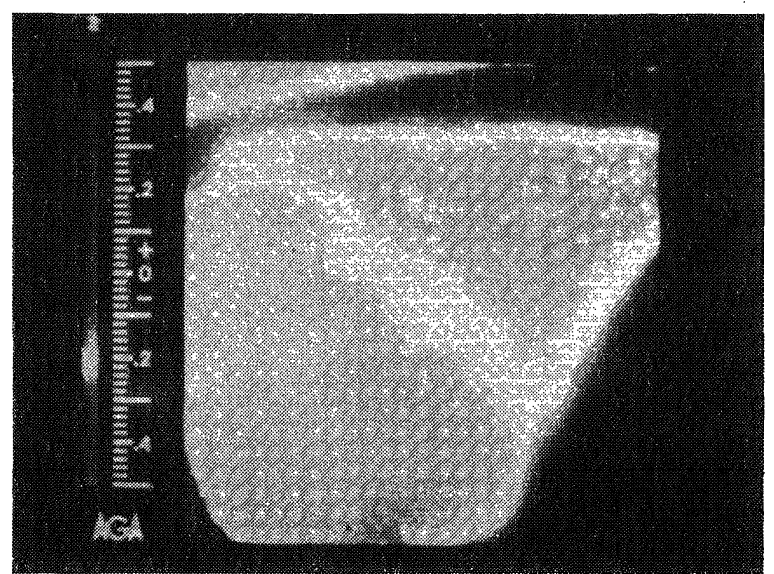

Foto 16
Hasta ahora se ha considerado la termografía como una técnica de medida superficial, pero existen algunos casos en los que es posible obtener medidas a una cierta profundidad. Las siguientes fotografías (13 y 14) son dos ejemplos en los que se puede observar la presencia de las viguetas y los pilares que forman parte de la estructura de un edificio.

Las fotografías 15 y 16 presentan una muestra de caliza de caras pulidas sumergida en una disolución de sosa y sometida a un ensayo de capilaridad. Esta muestra presenta algunas grietas en su cara superior a través de las cuales se observa el ascenso de agua y, por tanto, el descenso de temperatura en esa zona.
Until now, thermography has been considered as a technique for surface measurements, but there are certain cases in which it is possible to obtain measurements at a certain depth. Next thermographs (13 and 14) are two examples in which the presence of the beams and columns that form the structure of a building can be observed.

Thermographs 15 adn 16 show a sample fo lime with polished faces, submerged into a soda solution and subjected to a capillarity test. This sample shows some crackings on its upper face through which the ascension of water can be observed and, consequently, the descent of temperature in that zone. 


\section{DISCUSIÓN}

Como se ha podido comprobar, a través de los ejemplos anteriores, la Termografía Infrarroja es una técnica de ensayo no destructivos, muy rápida de usar y que permite conocer con un buen grado de exactitud la situación térmica de una superficie en un momento dado.

En algunos casos, una medida cualitativa puede ser suficiente. Por ejemplo, cuando sólo cambia una de las variables en el proceso y estamos seguros de que todos los factores de error afectan de igual forma a la superficie a medir. Éste es el caso de ejemplo II.1 (fugas térmicas en una estufa), en el que se buscan esencialmente cambios térmicos sobre la superficie. La variación de emisividad se puede considerar nula dado que toda la superficie es del mismo material y los cambios de temperatura no son tan intensos como producir variaciones en ella. Dado que la superficie es metálica y la radiación recibida es una composición de la emitida por el cuerpo y la reflejada por la superficie, en este caso esta radiación está afectada por mucho error (estamos recibiendo una radiación normal (cámara y objeto perpendiculares entre si) y, por eso, se puede considerar que este error es el mismo en todos los puntos de medida $y$, consecuentemente, las medidas son comparativas.

En otros casos, es necesario realizar medidas cuantitativas, fundamentalmente, cuando el proceso implica un cambio de ambas variables. En este caso, la termografía nos da un mapa de variación, y es necesario completar estas medidas para separar variaciones de temperatura de variaciones de emisividad. Se desarrollan dos tipos de medida: medidas directas e indirectas. La elección de uno $u$ otro método depende de distintos factores: accesibilidad de la zona, estado de la superficie para realizar un buen contacto con el termopar, etc.

Además, es necesario el conocimiento de la zona de estudio para poder hacer una buena interpretación de la termografía, dado que, normalmente, no se van a tener las condiciones óptimas de laboratorio, sino una combinación de distintos parámetros no siempre fáciles de controlar. Un estudio termográfico necesita del estudio de todos los posibles factores que de alguna forma alteran la medida. Estos factores pueden ser reales o no. Por ejemplo, un gradiente térmico, una corriente de aire o un foco térmico o luminoso producen una alteración real en la temperatura del cuerpo que se recoge con la cámara; una reflexión sobre una parte del cuerpo fortalece la radiación total de este punto y también produciría un aumento de temperatura respecto a otro punto de la superficie, aunque en este caso, no sería real.

\section{DISSCUSION}

As it can be verified from the foregoing examples, intrared thermography is a quick non-destructive technique which permits to find out the thermal state of a surface at a given time and with a good degree of accuracy.

In some cases, a qualitative measurement can be sufficient. For instance, when only one of the process variables changes and it is certain that all of the error factors equally affect the surface to be measured. Such is the case of example II.1 (thermal leaks in an oven), where thermal changes on the surface are essentially sought for. Since we are dealing with a metal surface and the radiation received is a composition of the radiation emitted by the body and that reflected by its surface, in this case the radiation is affected by a large error (a great deal of reflected radiation is being receive). On the other hand, a normal radiation is being received (the camera and the object are at ringht angles), so that it may be cosidered that the error is the same for all measuring points and consequently the mesaurements are comparable.

In other cases, it is required to carry out quantitative measurements, mainly when the process involves changes in both variables. In that case, thermography furnishes a map of the radiation variation, and it is necessary to complete these measurements in order to separte the temperature variations from the emissivity variations. Two types of measurements are carried out: direct and indirect measurements. The choice of either method depends on several factors: the accessibility of the area, the state of the surface as regards the establishment of a good contanct with the thermocouple, etc.

In addition, it is necessary to be acquainted with the area to be studied, in order to be able to make a correct interpretation of the thermograph, on account of the fact that, normally, it will not be operated under the optimum laboratory conditions, but under a combination of several parameters which are not always easy to control. $A$ thermographic study demands the study of all possible factors which in a way or another can alter the measurement. These factors may be either real or not: for example, a thermal gradient, an air draft or a thermal or luminous focus cause a real change of the body temperature recorded with the camera; a reflection on a point of the body strengthens the total radiation emitted by that point and would also cause a temperature increase with respect to another point in the surface, although in this case it would not be real. 
Un factor que puede alterar de forma importante las medidas es la distancia cámara-objeto. Cuando la distancia entre ambos es de $4 \mathrm{~m}$ ó más interviene, de forma importante, la atenuación atmosférica. El efecto de este parámetro se muestra en el ejemplo I.3. En dicho ejemplo se observa como para distintas distancias se tienen distintas temperaturas en los mismos puntos, si bien, se mantiene constante el gradiente de temperaturas en ambos casos. Esto lleva a dos conclusiones: en primer lugar, la distancia cámara-objeto ha de ser pequeña, siempre que sea posible, de forma que este factor no sea relevante y se obtengan medidas reales sobre la superficie; cuando esto no es posible, la distancia cámara-objeto debe mantenerse constante durante todas las medidas. En este caso, el valor puntual medido no sería representativo, pero sí la distribución cualitativa de temperaturas y su evolución temporal.

Se presentan, además, otros ejemplos en los que se obtienen imágenes a una pequeña profundidad. En algunos casos, cuando la radiación incidente sobre el cuerpo está reforzada por una longitud de onda determinada (en torno a $1 \mu$ ), la radiación electromagnética es capaz de penetrar un cierto espesor y reflejarse en una capa a una determinada profundidad. Esta radiación reflejada es la que se recoge con la cámara, de forma que somos capaces de "ver" lo que ocurre detrás de la pared.

Esta nueva aplicación de la técnica está aún muy poco desarrollada, aunque se han obtenido algunos resultado importantes en el estudio de pinturas antiguas. En cualquier caso, esta aplicación podría ser muy importante en la detección de delaminaciones a pequeña profundidad, en el control y protección de monumentos antiguos o en estudio de pinturas y otras obras de arte.

\section{CONCLUSIONES}

La Termografía Infrarroja es una técnica no destructiva de medida aplicable a cualquier fenómeno físico que conlleve una variación de temperatura o emisividad del cuerpo. No es necesario contacto entre el cuerpo y el equipo, lo cual, elimina posibles perturbaciones en la temperatura.

Es, además, una ténica rápida y aplicable a pie de obra, si bien, en este caso, habría que considerar distintas perturbaciones en la medida. Un primer barrido de la zona de estudio indica aquellos puntos en los que se produce un cambio de la radiación emitida. Posteriormente, sería necesario un estudio más detallado de la zona dañada. Este primer estudio nos daría un perfil real de variación de radiación sobre la superficie. Si estos datos se completan con el conocimiento
A factor that can substantially alter the measurements is the distance camera-object. When the distance separating both amounts to 4 $m$ or more, the atmospheric attenuation has a considerable influence. The effect of this parameter is shown in example 1.3. In this example, it is observed that, for the same points, different temperatures are obtained for different distances, although the temperature gradient keeps constant in both cases. This leads to two conclusions: in the first place, the camera-object distance must be small, if possible, so that this factor becomes irrelevant and real measurements on the surface are obtained; if this is not possible, the camera-object distance must be kept constant during all of the measurements. In that case, a puntual value measured would not be representative, but the qualitative distribution of temperatures and their temporal evolution will be so.

Other examples are presented too, in which images are obtained at a small depth. In some cases, when the radiation inciding on the body is reinforced by a determined wavelength (about $1 \mu$ ), electromagnetic radiation can penetrate a certain thickness and be reflected at a certain depth. This reflected radiation is that recorded by the camera, so that we can "see" what happens behind the wall.

This new application of the technique is still scarcely developed, although some important results have already been achieved in the study of old paintings. In any case, this application could be very important in the detection of delaminations at a small depth, as in the control and protection of ancient monuments or in the study of paintings and other works of art.

\section{CONCLUSIONS}

Infrared thermography is a non-destructive measurement technique applicable to any physical phenomenon involving a temperature or emissivity variation in the body. No contact between the body and the equipment is necessary, what eliminates possible disturbances in the temperature.

It is in addition a quick technique applicable on the site, although in the latter case consideration should be pain to various disturbances in the measurement. A first sweeping of the study area will indicate the points where a change in the radiation emitted will take place. Later on, a more detailed study of the damage area would be required. This first study would give a real profile of the radiation variation on the surface. If these data are completed with the knowledge of the 
de los posibles fenómenos físicos que están ocurriendo en el cuerpo ó con medidas realizadas por otras técnicas, se pueden obtener perfiles de temperatura, emisividad u otras variables que son el origen de estos cambios (humedad, espesores, etc.).

Una limitación importante de la técnica es el carácter superficial de sus medidas. Todos los resultados obtenidos se refieren a la superficie del cuerpo ó a una capa a muy poca profundidad, aunque ésta es una aplicación potencial que necesitaría de un estudio más detallado para su posterior aplicación.

\section{AGRADECIMIENTOS}

Este trabajo ha sido promovido por la Dirección General de Investigación Científica y Técnica (PAT91-1056-C03-03).

Agradecemos, también, a Juan José López del Amor su ayuda en la realización del material gráfico. possible physical phenomena that are taking place in the body or else with measurements taken by other techniques, the profiles or the temperature, emissivity or other variables at the source of these changes (moisture, thickness, etc.) can be obtained.

An important limitation of this techniques is the superficial nature of the measurements. All the results obtained refer to the body surface or a layer at a very small depth, although this is a potential application which would require a more detailed study with a view to future use.

\section{ACKNOWLEDGEMENTS}

This research has been conducted under the sponsorship of the Spanish Dirección General de Investigación Científica y Técnica.

We thank Juan José López del Amor for his valuable assitance.

\title{
REFERENCIAS (REFERENCES)
}

(1) SCHICKERT, R.: "Infrared thermography as a possible tool to detect damaged areas in buildings". SPIE Vol. 254. Thermosense III (1980) (pp. 11-117).

(2) PETTERSSON, B. and AXEN, B.: "Thermography testing of thermal insulation and Airtightness of Buildings". Editor: Bengt Steen. Printing: Spangbergs Tryckerier AB. Stockhholm (1980).

(3) Gaussorgues, G.: "La thermographie infrarouge. Principes Technologies-Applications". Technique et Documentation. Lavoisier (1989).

(4) HUDSON, R. D.: "Infrared Sistem Engineering". John Wiley Ans Sons (1969).

\section{Última monografía del ICCET/CSIC}

N. ${ }^{\circ} 409$

\section{OCLUSIÓN DE POROS POR TRATAMIENTO QUÍMICO}

\author{
FERNANDO TRIVIÑO VAZQUEZ \\ IGNACIO MENÉNDEZ DE PAZOS \\ ICCET/CSIC \\ FRANCISCO HERNÁNDEZ LÓPEZ \\ ETSICCPM
}

Madrid, junio 1992

Se usa el principio del producto de solubilidad para rellenar los poros de materiales de construcción, impregnándolos con dos sales que formen otra insoluble.

Se estudian, a diversas temperaturas, los materiales siguientes: morteros de cemento, ladrillos y escayolas, tratados con diversas sales cálcicas como impregnantes y oxalatos y carbonatos como precipitantes, obteniéndose de esta forma una ocupación de poros del orden del $70 \%$. 